\title{
Assessment of Patient Satisfaction Level to Dental Health Care Services in Indonesia
}

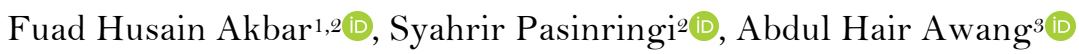

\begin{abstract}
${ }^{1}$ Department of Dental Public Health, Faculty of Dentistry, Hasanuddin University, Makassar, Indonesia.
${ }^{2}$ Hospital Administration Management, Faculty of Public Health, Hasanuddin University, Makassar, Indonesia.

${ }^{3}$ Faculty of Social Sciences and Humanities, National University of Malaysia, Selangor, Malaysia.
\end{abstract}

Author to whom correspondence should be addressed: Fuad Husain Akbar, Department Dental Public Health, Faculty of Dentistry, Hasanuddin University, Indonesia. 90245. Phone: +62 81243422362. E-mail: fuadgi2@gmail.com.

Academic Editors: Alessandro Leite Cavalcanti and Wilton Wilney Nascimento Padilha

Received: 16 July 2019 / Accepted: 18 April 2020 / Published: 04 May 2020

How to cite this article: Akbar FH, Pasinringi S, Awang AH. Assessment of patient satisfaction level to dental health care services in Indonesia. Pesqui Bras Odontopediatria Clín Integr. 2020; 20:e4825. https://doi.org/10.1590/pboci.2020.077

\begin{abstract}
Objective: To know the level of patient satisfaction with dental healthcare services in Bantaeng, Indonesia. Material and Methods: This pilot pathfinder survey was conducted at Dental and Oral Health Services in Bantaeng and Pa'jukukang Sub-districts of Bantaeng Regency of South Sulawesi Indonesia. The ShortForm Patient Satisfaction Questionnaire (PSQ-18) scaled was used and it consists of 18 questions and seven subscales. The t-test and ANOVA were used with a significance level set at $5 \%(\mathrm{p}<0.05)$. Results: The female participation (72.8\%) was greater than the male (27.2). Regarding age, $74.6 \%$ were $<40$ years, $21.1 \%$ were between $40-60$ years old and $4.4 \%$ were over 60 years old. On the subscale of technical quality, there was significant value in the age variable $(\mathrm{p}=0.45)$, education level $(\mathrm{p}=0.031)$, job $(\mathrm{p}=0.026)$, waiting time $(\mathrm{p}=0.46)$, distance to dentist $=0.026)$, and location $(\mathrm{p}=0.007)$. There were significant values on the interpersonal aspect subscale that were present at age $(p=0.016)$, education level $(p=0.038)$, and occupation $(\mathrm{p}=0.007)$. The highest satisfaction score was found on the technical quality subscale $(13.04 \pm 1.75)$ and the lowest satisfaction score was seen on the general satisfaction subscale $(4.11 \pm 1.75)$. There was a significant difference between the value of patient satisfaction with age, education, and occupation. Conclusion: Patients from the District Bantaeng and Pa'jukukang Bantaeng regency of South Sulawesi were more satisfied with the service provided. The highest satisfaction score was found on the technical quality subscale and the lowest satisfaction score was found in the general satisfaction subscale.
\end{abstract}

Keywords: Patient Satisfaction; Quality Indicators, Health Care; Comprehensive Dental Care. 


\section{Introduction}

Patient satisfaction is an important measurement result for healthcare and as defined by Pascoe, patient satisfaction is the patient's response to a significant aspect of his or her healthcare experience [1]. Donabedian said that patient satisfaction is essential as a measure of the quality of care because it provides information about the success of the service provider in meeting the patient's values and expectations, the issues on which the patient's authority is based. And also said that health services can be evaluated according to the structure, work process, results, and user satisfaction [Q-4]. Patient satisfaction with healthcare can be assessed from various dimensions, such as general satisfaction, technical quality, interpersonal aspects, communication, financial, time spent in the dentist, and access/convenience [5].

A total of $25.9 \%$ of Indonesians have dental and oral problems in the last 12 months (potential demand). In South Sulawesi, Indonesia has a high dental and mouth problem (>35\%) of $36.2 \%$ with an Effective Medical Demand (EMD) score of 10.3\% [5]. This can be due to the insufficient number of medical personnel and facilities/access. Bantaeng is one of the districts in South Sulawesi [6]. In Bantaeng District Health Profile 2016, the number of health personnel and facilities/access for health services in Bantaeng Regency in 2016 is still considered inadequate. The aim of this study was to determine the level of patient satisfaction on dental and oral healthcare services in Bantaeng and Pa'jukukang Sub-districts of Bantaeng Regency of South Sulawesi.

\section{Material and Methods}

Study Design and Sample

This pilot pathfinder survey was conducted in Dental and Oral Health Services in Bantaeng and Pa'jukukang Sub-districts of Bantaeng Regency of South Sulawesi from 29th - 31st January 2018. This study had a non-probabilistic sample comprising 114 participants.

\section{Data Collection}

Trained researchers collected data. To assess the level of patient satisfaction, the short-form Patient Satisfaction Questionnaire (PSQ-18) was taken from a previous study [7,8], which was preceded by several questions about demographic data (gender, age, education level and occupation) and visit (type, waiting time, distance and location). Standardized PSQ-18 questionnaires include 18 statements focusing on the quality of healthcare services provided. Respondents are free to choose the answer on a five-point Likert scale ranging from one (strongly agree) to five (strongly disagree). Statements are divided into 7 subscales: General satisfaction (Q3 and Q17); technical quality $\left(\mathrm{Q}^{2}, \mathrm{Q}^{4}, \mathrm{Q} 6\right.$, and Q14); Interpersonal aspects (Q10 and Q11); Communications (Q1 and Q13); Financials aspects (Q5 and Q7); Time spent with the doctor (Q12 and Q15); Access/convenience $(\mathrm{Q} 8, \mathrm{Q} 9, \mathrm{Q} 16$, and $\mathrm{Q} 18)$. Based on the results of the class interval calculation found that the level of satisfaction range to not satisfied (18-54) and satisfied (55-90).

Data Analysis

Data were analyzed using IBM SPSS Statistics for Windows Software, version 23 (IBM Corp., Armonk, NY, USA). Descriptive statistics were used to calculate the absolute and relative frequencies, mean and standard deviation. The t-test and ANOVA were used with a significance level set at $5 \%(\mathrm{p}<0.05)$. 
Permission was obtained from Faculty of Dentistry, Ethics and Research Advisory Committee, Hasanuddin University (Protocol No. 0246/PLo1/KEPK FKG RSGM UNHAS/2018). Informed consent was obtained from all the subjects.

\section{Results}

The female participation (72.8\%) was greater than the male (27.2). Regarding age, $74.6 \%$ were $<40$ years, $21.1 \%$ were between $40-60$ years old and $4.4 \%$ were over 60 years old. Table 1 shows the distribution of 114 subjects based on demographic characteristics. Most participants had junior high school education level $(37.7 \%)$, were students/university students $(43.0 \%)$, revealed an early waiting time $(41.2 \%)$ and $77.2 \%$ were from the urban area.

Table 1. Subject distribution based on demographic characteristics.

\begin{tabular}{|c|c|c|c|}
\hline Variables & Categories & $\mathbf{N}$ & $\%$ \\
\hline \multirow[t]{9}{*}{ Education Level } & Uneducated & 2 & 1.8 \\
\hline & Elementary & 13 & 11.4 \\
\hline & Incomplete Elementary & 0 & 0.0 \\
\hline & Junior High School (JHS) & 43 & 37.7 \\
\hline & Incomplete JHS & 1 & 0.9 \\
\hline & High School (HS) & 34 & 29.8 \\
\hline & Incomplete HS & 2 & 1.8 \\
\hline & Diploma & 6 & 5.3 \\
\hline & Bachelor & 13 & 11.4 \\
\hline \multirow[t]{6}{*}{ Occupation } & Student/University Student & 49 & 43.0 \\
\hline & Government Employee/Police/Pensioners & 18 & 15.8 \\
\hline & Private Employee & 7 & 6.1 \\
\hline & Entrepreneur & 21 & 18.4 \\
\hline & Housewives & 14 & 12.3 \\
\hline & Others & 5 & 4.4 \\
\hline \multirow[t]{2}{*}{ Type of Visit } & First Visit & 57 & 50.0 \\
\hline & Not First Visit & 57 & 50.0 \\
\hline \multirow[t]{3}{*}{ Waiting Time } & Faster & 47 & 41.2 \\
\hline & On Time & 32 & 28.1 \\
\hline & Late & 35 & 30.7 \\
\hline \multirow[t]{3}{*}{ Distance to the Dentist } & Far & 44 & 38.6 \\
\hline & Moderate & 45 & 39.5 \\
\hline & Near & 25 & 21.9 \\
\hline \multirow[t]{2}{*}{ Location } & Urban (Bantaeng Sub-District) & 88 & 77.2 \\
\hline & Rural (Pa'jukukang Sub-District) & 26 & 22.8 \\
\hline
\end{tabular}

Table 2 shows that female patients being satisfied $(55.42 \pm 6.42)$ while with male patients being dissatisfied $(54.35 \pm 4.78)$. There was a significant difference between age and dental healthcare service satisfaction $(\mathrm{p}=0.001)$. The highest satisfaction value at the level of education finished elementary $(57.77 \pm$ 4.73). There was a significant difference between education level and dental healthcare service satisfaction $(p=0.042)$ and between occupation and satisfaction of dental healthcare service $(p=0.005)$. The first and repeat visits were satisfied with the satisfaction score of $55.02 \pm 6.40$ and $55.25 \pm 5.67$. Medium distances to the dentist had the highest satisfaction score $(55.84 \pm 6.47)$ compared to the others. Patients in rural area were satisfied with the given dental healthcare service $(56.73 \pm 8.36)$ while the urban patients were dissatisfied $(54.66 \pm 5.10)$. 
Table 2. Mean difference in dental health service satisfaction scores.

\begin{tabular}{|c|c|c|c|c|c|c|c|c|c|c|c|c|c|c|}
\hline \multirow[t]{2}{*}{ Variables } & \multicolumn{2}{|c|}{ General Satisfaction } & \multicolumn{2}{|c|}{ Technical Quality } & \multicolumn{2}{|c|}{ Interpersonal Aspect } & \multicolumn{2}{|c|}{ Communication } & \multicolumn{2}{|c|}{ Financial } & \multicolumn{2}{|c|}{ Time Spent ${ }^{\#}$} & \multicolumn{2}{|c|}{ Access/Comfort } \\
\hline & Mean (SD) & p-value & Mean (SD) & p-value & Mean (SD) & $\mathrm{p}$-value & Mean (SD) & p-value & Mean (SD) & $\mathrm{p}$-value & Mean (SD) & p-value & Mean (SD) & $\mathrm{p}$-value \\
\hline \multicolumn{15}{|l|}{ Gender } \\
\hline Male & $4.84 \pm 2.10$ & $0.006^{*}$ & $13.19 \pm 2.20$ & 0.726 & $6.23 \pm 1.06$ & 0.131 & $5.65 \pm 1.40$ & 0.446 & $6.19 \pm 0.83$ & 0.163 & $6.10 \pm 0.65$ & $0.000^{*}$ & $12.16 \pm 2.46$ & 0.760 \\
\hline Female & $3.84 \pm 1.53$ & & $12.98 \pm 3.17$ & & $6.75 \pm 1.79$ & & $5.86 \pm 1.27$ & & $6.63 \pm 1.64$ & & $7.07 \pm 1.40$ & & $12.30 \pm 2.05$ & \\
\hline \multicolumn{15}{|l|}{ Age } \\
\hline$<40$ Years & $4.19 \pm 1.82$ & 0.738 & $13.41 \pm 3.17$ & $0.045^{* *} *$ & $6.82 \pm 1.75$ & $0.034 * *$ & $5.79 \pm 1.41$ & 0.777 & $6.69 \pm 1.57$ & 0.069 & $6.96 \pm 1.39$ & 0.073 & $12.42 \pm 2.37$ & 0.390 \\
\hline 40-60 Years & $3.92 \pm 1.56$ & & $12.13 \pm 1.70$ & & $6.08 \pm 1.10$ & & $5.75 \pm 0.99$ & & $5.96 \pm 1.08$ & & $6.42 \pm 1.02$ & & $11.75 \pm 1.36$ & \\
\hline$>60$ Years & $3.80 \pm 1.64$ & & $11.00 \pm 1.00$ & & $5.40 \pm 0.55$ & & $6.20 \pm 0.84$ & & $6.00 \pm 0.00$ & & $6.00 \pm 0.00$ & & $12.00 \pm 1.00$ & \\
\hline \multicolumn{15}{|l|}{ Education Level } \\
\hline Uneducated & $3.50 \pm 2.12$ & 0.636 & $12.00 \pm 0.00$ & $0.031 * *$ & $6.00 \pm 0.00$ & $0.038^{* *}$ & $6.00 \pm 0.00$ & 0.317 & $6.00 \pm 0.00$ & 0.537 & $5.50 \pm 0.71$ & 0.131 & $11.00 \pm 1.41$ & 0.773 \\
\hline Elementary & $3.54 \pm 1.13$ & & $11.46 \pm 2.54$ & & $6.31 \pm 1.18$ & & $6.15 \pm 1.07$ & & $6.31 \pm 1.55$ & & $6.77 \pm 1.42$ & & $12.23 \pm 0.83$ & \\
\hline Junior High School (JHS) & $4.00 \pm 1.84$ & & $14.07 \pm 3.02$ & & $7.33 \pm 1.96$ & & $5.79 \pm 1.52$ & & $6.93 \pm 1.92$ & & $7.23 \pm 1.59$ & & $12.26 \pm 2.61$ & \\
\hline Incomplete JHS & $3.00 \pm 0.00$ & & $13.00 \pm 0.00$ & & $6.00 \pm 0.00$ & & $6.00 \pm 0.00$ & & $7.00 \pm 0.00$ & & $8.00 \pm 0.00$ & & $13.00 \pm 0.00$ & \\
\hline High School (HS) & $4.44 \pm 1.94$ & & $13.29 \pm 2.74$ & & $6.03 \pm 1.40$ & & $5.35 \pm 1.15$ & & $6.24 \pm 0.96$ & & $6.47 \pm 0.96$ & & $12.12 \pm 2.16$ & \\
\hline Incomplete HS & $3.00 \pm 1.41$ & & $12.00 \pm 0.00$ & & $6.00 \pm 0.00$ & & $6.00 \pm 0.00$ & & $6.00 \pm 0.00$ & & $6.00 \pm 0.00$ & & $10.50 \pm 2.12$ & \\
\hline Diploma & $4.83 \pm 1.60$ & & $11.67 \pm 2.34$ & & $6.00 \pm 0.63$ & & $6.50 \pm 0.84$ & & $6.17 \pm 0.75$ & & $6.33 \pm 0.52$ & & $12.33 \pm 1.03$ & \\
\hline Bachelor & $4.23 \pm 1.59$ & & $11.46 \pm 2.96$ & & $6.54 \pm 1.27$ & & $6.23 \pm 1.30$ & & $6.31 \pm 1.11$ & & $6.77 \pm 1.09$ & & $13.08 \pm 1.98$ & \\
\hline \multicolumn{15}{|l|}{ Occupation } \\
\hline Student/Univ. Student & $4.02 \pm 1.90$ & 0.116 & $13.86 \pm 2.89$ & $0.026^{* *}$ & $7.22 \pm 1.91$ & $0.007^{*} *$ & $5.84 \pm 1.37$ & 0.610 & $6.76 \pm 1.76$ & 0.741 & $7.27 \pm 1.50$ & $0.031^{*}$ & $12.49 \pm 2.59$ & 0.489 \\
\hline Government Employee ${ }^{\star}$ & $4.83 \pm 1.82$ & & $12.50 \pm 2.79$ & & $5.72 \pm 1.13$ & & $6.17 \pm 1.38$ & & $6.28 \pm 1.13$ & & $6.17 \pm 0.51$ & & $11.78 \pm 1.90$ & \\
\hline Private Employee & $4.14 \pm 1.35$ & & $12.14 \pm 2.34$ & & $6.57 \pm 0.98$ & & $5.43 \pm 0.79$ & & $6.29 \pm 0.76$ & & $6.43 \pm 1.13$ & & $12.86 \pm 2.04$ & \\
\hline Entrepreneur & $4.33 \pm 1.80$ & & $13.43 \pm 2.89$ & & $6.43 \pm 1.08$ & & $5.52 \pm 1.33$ & & $6.43 \pm 1.29$ & & $6.52 \pm 1.08$ & & $12.05 \pm 1.83$ & \\
\hline Housewives & $3.79 \pm 0.97$ & & $11.07 \pm 2.37$ & & $5.86 \pm 1.51$ & & $5.64 \pm 1.34$ & & $6.36 \pm 1.55$ & & $6.64 \pm 1.22$ & & $11.71 \pm 1.27$ & \\
\hline Others & $2.40 \pm 0.89$ & & $12.00 \pm 3.67$ & & $6.60 \pm 1.34$ & & $6.20 \pm 0.45$ & & $6.00 \pm 0.00$ & & $6.80 \pm 1.79$ & & $13.40 \pm 1.52$ & \\
\hline \multicolumn{15}{|l|}{ Type of Visit } \\
\hline First Visit & $4.21 \pm 1.83$ & 0.559 & $13.00 \pm 3.16$ & 0.899 & $6.77 \pm 1.73$ & 0.279 & $5.60 \pm 1.28$ & 0.099 & $6.60 \pm 1.44$ & 0.527 & $6.67 \pm 1.38$ & 0.257 & $12.18 \pm 2.41$ & 0.666 \\
\hline Not First Visit & $4.02 \pm 1.68$ & & $13.07 \pm 2.70$ & & $6.44 \pm 1.54$ & & $6.00 \pm 1.31$ & & $6.42 \pm 1.51$ & & $6.95 \pm 1.25$ & & $12.35 \pm 1.89$ & \\
\hline \multicolumn{15}{|l|}{ Waiting Time } \\
\hline Faster & $3.85 \pm 1.82$ & 0.410 & $13.79 \pm 2.71$ & $0.046^{* *}$ & $6.55 \pm 1.46$ & 0.090 & $5.62 \pm 1.09$ & 0.446 & $6.28 \pm 1.75$ & 0.314 & $7.23 \pm 1.48$ & $0.003 * *$ & $12.11 \pm 2.01$ & $0.034 * *$ \\
\hline On Time & $4.31 \pm 1.67$ & & $12.84 \pm 3.18$ & & $6.19 \pm 1.80$ & & $5.88 \pm 1.54$ & & $6.78 \pm 1.39$ & & $6.78 \pm 1.13$ & & $13.06 \pm 1.78$ & \\
\hline Late & $4.29 \pm 1.74$ & & $12.20 \pm 2.78$ & & $7.06 \pm 1.64$ & & $5.97 \pm 1.34$ & & $6.57 \pm 1.07$ & & $6.26 \pm 1.04$ & & $11.74 \pm 2.49$ & \\
\hline \multicolumn{15}{|l|}{ Distance to the Dentist } \\
\hline Far & $3.89 \pm 1.54$ & 0.146 & $13.14 \pm 2.49$ & $0.026^{* * *}$ & $6.66 \pm 1.51$ & 0.931 & $5.98 \pm 1.09$ & 0.376 & $6.45 \pm 1.82$ & 0.614 & $7.02 \pm 1.52$ & 0.266 & $12.61 \pm 1.91$ & 0.31 \\
\hline Moderate & $4.51 \pm 2.04$ & & $13.67 \pm 3.08$ & & $6.53 \pm 1.56$ & & $5.78 \pm 1.52$ & & $6.67 \pm 1.28$ & & $6.78 \pm 1.26$ & & $11.91 \pm 2.03$ & \\
\hline Near & $3.80 \pm 1.44$ & & $11.72 \pm 3.03$ & & $6.64 \pm 2.02$ & & $5.52 \pm 1.23$ & & $6.32 \pm 1.07$ & & $6.48 \pm 0.96$ & & $12.28 \pm 2.72$ & \\
\hline \multicolumn{15}{|l|}{ Location } \\
\hline Urban & $4.01 \pm 1.57$ & 0.252 & $12.64 \pm 2.78$ & $0.007^{*}$ & $6.57 \pm 1.57$ & 0.659 & $5.92 \pm 1.13$ & 0.066 & $6.47 \pm 1.41$ & 0.569 & $6.78 \pm 1.28$ & 0.734 & $12.27 \pm 2.00$ & 0.931 \\
\hline Rural & $4.46 \pm 2.27$ & & $14.38 \pm 3.05$ & & $6.73 \pm 1.89$ & & $5.38 \pm 1.75$ & & $6.65 \pm 1.67$ & & $6.88 \pm 1.45$ & & $12.23 \pm 2.66$ & \\
\hline TOTAL & $4.11 \pm$ & 753 & $13.04 \pm 0$ & .926 & $6.61 \pm$ & 638 & $5.80 \pm$ & & $6.51 \pm$ & 471 & $6.81 \pm$ & .316 & $12.26 \pm$ & 2.116 \\
\hline
\end{tabular}

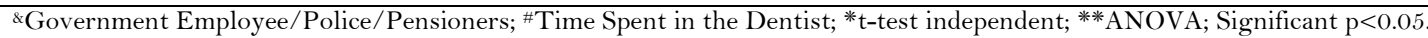


There was a significant value on the time subscale spent with the dentist seen in the gender $(p<0.001)$, employment $(p=0.031)$, and at the waiting time $(p=0.003)$. This suggests a significant difference between time spent with doctors with gender, occupation, and waiting times. Patients with a timely waiting time were significantly more satisfied with the dental healthcare service on the access/comfort subscale $(p=0.003)$ than the other waiting time. The highest satisfaction score was found on the technical quality subscale $(13.04 \pm$ $1.75)$ and the lowest satisfaction score was seen on the general satisfaction subscale $(4.11 \pm 1.75)$.

Table 3 presents that men showed significantly more satisfaction on the general satisfaction subscale of dental healthcare services than women $(4.84 \pm 2.10$ and $3.84 \pm 1.53, p=0.006)$. Age, education, occupation, type of visit, waiting time, distance, and location have almost no effect on the general satisfaction subscale of dental healthcare services. On the subscale of technical quality, there was significant value in the age variable $(\mathrm{p}=0.045)$, education level $(\mathrm{p}=0.031)$, job $(\mathrm{p}=0.026)$, waiting time $(\mathrm{p}=0.046)$, distance to dentist $=0.026)$, and location $(p=0.007)$. There were significant values on the interpersonal aspect subscale that were present at age ( $\mathrm{p}=0.016)$, education level $(\mathrm{p}=0.038)$, and occupation $(\mathrm{p}=0.007)$. On the communication and financial subscale there was no significant difference between communication and finance with gender, age, education level, occupation, type of visit, waiting time, distance to the dentist, and location.

Table 3. Difference in the total mean value of dental healthcare service satisfaction.

\begin{tabular}{|c|c|c|c|}
\hline Variables & Categories & Mean (SD) & p-value \\
\hline \multirow[t]{2}{*}{ Gender } & Male & $54.35( \pm 4.78)$ & 0.402 \\
\hline & Female & $55.42( \pm 6.42)$ & \\
\hline \multirow[t]{3}{*}{ Age } & $<40$ Years & $56.68( \pm 6.42)$ & $0.001^{*}$ \\
\hline & $40-60$ Years & $53.05( \pm 4.05)$ & \\
\hline & $>60$ Years & $50.89( \pm 2.47)$ & \\
\hline \multirow[t]{8}{*}{ Education Level } & Uneducated & $50.00( \pm 0.00)$ & $0.042^{*}$ \\
\hline & Elementary & $57.77( \pm 4.73)$ & \\
\hline & Junior High School (JHS) & $57.60( \pm 6.63)$ & \\
\hline & Incomplete JHS & $56.00( \pm 0.00)$ & \\
\hline & High School (HS) & $53.94( \pm 5.56)$ & \\
\hline & Incomplete HS & $49.50( \pm 3.54)$ & \\
\hline & Diploma & $53.83( \pm 2.40)$ & \\
\hline & Bachelor & $54.62( \pm 5.85)$ & \\
\hline \multirow[t]{6}{*}{ Occupation } & Student/University Student & $57.45( \pm 6.53)$ & $0.005^{*}$ \\
\hline & Government Employee/Police/Pensioners & $53.44( \pm 5.00)$ & \\
\hline & Private Employee & $53.86( \pm 3.02)$ & \\
\hline & Entrepreneur & $54.71( \pm 5.48)$ & \\
\hline & Housewives & $51.07( \pm 3.87)$ & \\
\hline & Others & $53.40( \pm 7.09)$ & \\
\hline \multirow[t]{2}{*}{ Type of Visit } & First Visit & $55.02( \pm 6.40)$ & 0.841 \\
\hline & Not First Visit & $55.25( \pm 5.67)$ & \\
\hline \multirow[t]{3}{*}{ Waiting Time } & Faster & $55.43( \pm 6.05)$ & 0.450 \\
\hline & On Time & $55.84( \pm 6.20)$ & \\
\hline & Late & $54.09( \pm 5.86)$ & \\
\hline \multirow[t]{3}{*}{ Distance to the Dentist } & Far & $55.75( \pm 5.65)$ & 0.082 \\
\hline & Moderate & $55.84( \pm 6.47)$ & \\
\hline & Near & $52.76( \pm 5.42)$ & \\
\hline \multirow[t]{2}{*}{ Location } & Urban & $54.66( \pm 5.10)$ & 0.124 \\
\hline & Rural & $56.73( \pm 8.36)$ & \\
\hline
\end{tabular}

*Statistically significant. 


\section{Discussion}

Patient's satisfaction with the health service provided by the doctor is very important. Thus, it is essential to identify weaknesses in the service system to help improve through patient opinion. This can be done using Patient Satisfaction Questionaire short form (PSQ-18), a validated tool that can be applied to various situations and can compare interventions [7].

In Table 2, the highest value of health service satisfaction is found on the technical quality subscale. Technical quality contains the competencies of service providers and adherence to high standards of diagnosis and treatment (accuracy, precision, unnecessary risks, making mistakes). Technical quality has a strong relationship with overall satisfaction. Other authors have also obtained similar results in their study [9]. While the lowest satisfaction score is found on the subscale of general satisfaction and communication. Communication errors between the service provider and the patient may result in a medical failure affecting the patient's condition. The communication-centered approach between communication service providers and patients is regarded a good strategy in creating relationships with patients and is considered a key to improving the quality of health services. The results obtained in this survey are similar to those previously previously reported in the literature [10].

Table 3 shows that the female variable is satisfied while the male feels satisfied. On women, the satisfaction level was higher than men's. Gender has an influence on the services provided. Women are more conscientious in appearance, while men do not care about it [11]. These findings have also been shown in previous studies [10,12].

In this study, the age variable found that the older the patient was not satisfied with the service. However, other studies have reported different findings. Previous research has found that older patient has higher level satisfaction [10,13]. This survey found that lower education has higher-level service satisfaction. This may occur because patients with higher education levels expecting better health care services compared to patients with low levels of education, confirming previous findings [4].

For patient satisfaction, the first visit and not the first visit in this study did not show a significant difference in all subscales of health services. This result is similar to the findings of other authors [1], who claim that there is no significant difference, but found high levels of satisfaction. Other studies reported that the difference between first and recurrent patient visits from all dimensions of quality of healthcare is not significant [2,14]. Previous research cannot demonstrate that first-time patients tend to provide a higher satisfaction assessment than recurrent-return patients as reported on emergency medical services [1]. These findings are consistent with studies that found no difference in satisfaction among first-time patients with recurrent patient visits at clinics in the UK [15].

The level of patient satisfaction at the waiting time of the majority of patients was satisfied with the service, and this is similar to the previously reported showing that long waiting time for treatment is a major problem for patient dissatisfaction [16]. Waiting time in the examination room has a more significant negative effect on patient satisfaction than the time spent in the waiting room, and first-time patients are very sensitive to waiting time [17]. Most importantly, longer waiting times can actually reduce the patient's perception of the physician's ability and reduce confidence in the care provided [18].

The level of satisfaction at the rural location is higher than urban. But only on technical quality subscales that have significant value. Rural patients were generally more satisfied with health services than urban and suburban populations. It can be explained that urban residents have the possibility to choose professional care from health care providers [4,19-26]. 


\section{Conclusion}

Patients from the District Bantaeng and Pa'jukukang Bantaeng regency of South Sulawesi were more satisfied with the service provided. The highest satisfaction score was found on the technical quality subscale and the lowest satisfaction score was found in the general satisfaction subscale.

\section{Authors' Contributions}

FHA (D) 0000-0003-4819-4820 $\begin{aligned} & \text { Supervision, Conceptualization, Methodology, Investigation, Formal Analysis, } \\ & \text { Resources, Validation, Writing - Original Draft Preparation and Writing - Review } \\ & \text { and Editing. } \\ & \text { Supervision, Methodology, Investigation, Formal Analysis, Data Curation and } \\ & \text { Writing - Review and Editing. }\end{aligned}$
$\begin{array}{lll}\text { SP } & \text { Formal Analysis, Resources and Writing - Review and Editing. } \\ \text { All authors declare that they contributed to critical review of intellectual content and approval of the final version to be } \\ \text { published. }\end{array}$

\section{Financial Support}

None.

\section{Conflict of Interest}

The authors declare no conflicts of interest.

\section{References}

[1] Mthethwa SR, Chabikuli NJ. Comparing repeat and first visit patients' satisfaction with service quality at Medunsa Oral Health Centre. SADJ 2016; 71(10):454-9.

[2] Aldosari MA, Tavares MA, Matta-Machado ATG, Abreu MHNG. Factors associated with patients' satisfaction in Brazilian dental primary health care. PLoS ONE 2017; 12(11):e0187993. https://doi.org/10.1371/journal.pone.0187993

[3] Al-Abri R, Al-Balushi A. Patient satisfaction survey as a tool towards quality improvement. Oman Med J 2014; 29(1):3-7. https://doi.org/10.5001/omj.2014.02

[4] Ganasegeran K, Perianayagam W, Manaf RA, Jadoo SA, Al-Dubai SA. Patient satisfaction in Malaysia's busiest outpatient medical care. Scientific World Journal 2015; 2015:714754. https://doi.org/10.1155/2015/714754

[5] Riset Kesehatan Dasar Riskesdas 2013. Available from: http://www.depkes.go.id/resources/download/general/ Hasil\%20Riskesdas\%202013.pdf. [Accessed on February 3, 2018]. [In Indonesian]

[6] Profil Kesehatan Tahun 2014. Available from: http://www.depkes.go.id/resources/download/profil/ PROFIL_KAB_KOTA_2014/ 7303_Sulsel_Kab_Bantaeng_2014.pdf. [Accessed on February 3, 2018]. [In Indonesian]

[7] Thayaparan AJ, Mahdi E. The Patient Satisfaction Questionnaire Short Form (PSQ-18) as an adaptable, reliable, and validated tool for use in various settings. Med Educ Online 2013; 18:21747. https://doi.org/10.3402/meo.v18io.21747

[8] Ali DA. Patient satisfaction in dental healthcare centers. Eur J Dent 2016; 10(3):309-14. https://doi.org/10.4103/1305-7456.184147

[9] Ziaei H, Katibeh M, Eskandari A, Mirzadeh M, Rabbanikah Z, Javadi MA. Determinants of patient satisfaction with ophthalmic services. BMC Res Notes 2011; 4:7. https://doi.org/10.1186/1756-0500-4-7

[10] Samohyl M, Nadazdyova A, Hirjak M, Argalasova L, Hirosova K, Jurkovicova J. The satisfaction level of patients seeking dental care in the Slovak Republic: a cross-sectional questionnaire study. Iran J Public Health 2017; 46(8):1143-4.

[11] Akbar FH, Pratiwi R. Patient Satisfaction against the quality of dental health services at dental polyclinic of Tenriawaru General Hospital in Bone Regency. J Dentomaxillofac Sci 1(3):177-84. https://doi.org/10.15562/jdmfs.v 1 i3.313

[12] Holikatti PC, Kar N, Mishra A, Shukla R, Swain SP, Kar Y. A study on patient satisfaction with psychiatric services. Indian J Psychiatry 2012; 54(4):327-32. https://doi.org/10.4103/0019-5545.104817

[13] Voutilainen A. Meta-analysis: complex relationships between patient satisfaction, age and item-level response rate. J Res Nurs 2016; 21(8):611-20. https://doi.org/10.1177/1744987116655595 
[14] Loberto LL, Martin L, Paula de B, Fereira E. Disatisfaction with the dental services and associated factors among adults. Cienc Saúde Coletiva 2015; 22(5):1601-13. https://doi.org/10.1590/1413-81232017225.17362015

[15] Patel JY. A study on evaluation of patient satisfaction with dental health care services. Int J Sci Res Pub 2014; 4:1-4.

[16] Bhat N, Sultane P, Chhabra S, Choudhary SN, Sen N, Patel D, et al. Assessment of patient satisfaction toward dental care services of patients visiting dental schools in Udaipur, Rajasthan, India. Int J Oral Care Res 2017; 5(1):34-41. https://doi.org/10.5005/jp-journals-10051-0079

[17] Arain M, Nicholl J, Campbell M. Patients' experience and satisfaction with GP led walk-in centers in the UK: a crosssectional study. BMC Health Serv Res 2013; 13:142. https://doi.org/10.1186/1472-6963-13-142

[18] Bleustein C, Rothschild DB, Valen A, Valatis E, Schweitzer L, Jones R. Wait times, patient satisfaction scores, and the perception of care. Am J Manag Care 2014; 20(5):393-400.

[19] Spasojevic N, Vasilj I, Hrabac B, Celik D. Rural - urban difference in health care quality assesment. Mater Sociomed 2015; 27(6):409-11. https://doi.org/10.5455/msm.2015.27.409-411

[20] Samad R, Akbar FH, Pasiga BD, Pratiwi R, Anwar AI, Djamaluddin N, et al. Evaluation of patient satisfaction on quality of public dental health service from different dimensions in Indonesia. Pesqu Bras Odontopediatria Clin Integr 2018; 18(1):e4033. https://doi.org/10.4034/PBOCI.2018.181.49

[21] Akbar FH, Pasiga B. Patient satisfaction level with health care quality at dental hospital of Hasanuddin University. Adv Social Sci Educ Human Res 2017; 2017. https://doi.org/10.2991/icaaip-17.2018.59

[22] Akbar FH, Pratiwi R, Cendikiawan R. Relationship between oral health status with knowledge, attitude, and behavior of elementary school children. J Int Dent Med Res 2017; 10(3):920-6.

[23] Husain FA, Tatengkeng F. Oral health-related quality of life appraised by OHIP-14 between urban and rural areas in Kutai Kartanegara Regency, Indonesia: pilot pathfinder survey. Open Dent J 2017; 11:557-64. https://doi.org/10.2174/1874210601711010557

[24] Akbar FH, Pratiwi R, Samad R, Fanissa F. Patient satisfaction on health service center in urban and rural area. Adv Health Sci Res 2017; 2:92-9. https://doi.org/10.2991/hsic-17.2017.14

[25] Akbar FH, Ayuandika U. Gender and age differences in patient satisfaction with dental care in the urban and rural areas of Indonesia: pilot pathfinder survey. Pesqui Bras Odontopediatria Clin Integr 2018; 18(1):e4093. https://doi.org/10.4034/PBOCI.2018.181.80

[26] Akbar FH, Jaya MT. Relationship between service quality on public health center and patient satisfaction. Glob J Health Sci 2017; 9(7):96-102. https://doi.org/10.5539/gjhs.v9n7p96 